\title{
Phyto- and Endogenous Estrogens Differently Activate Intracellular Calcium Ion Mobilization in Bovine Endometrial Cells
}

\author{
Izabela WOCLAWEK-POTOCKA ${ }^{1)}$, Krzysztof BORKOWSKI'), \\ Anna KORZEKWA ${ }^{1)}$, Kiyoshi OKUDA ${ }^{3)}$ and Dariusz J. SKARZYNSKI' ${ }^{1)}$ \\ ${ }^{1)}$ Department of Reproductive Immunology, Institute of Animal Reproduction and Food \\ Research, Polish Academy of Sciences, 10-747 Olsztyn, ${ }^{2)}$ OLYMPUS Poland, 00-236 Warsaw, \\ Poland and ${ }^{3)}$ Laboratory of Reproductive Endocrinology, Graduate School of Natural Sciences \\ and Technology, Okayama University, Okayama 700-8530, Japan
}

\begin{abstract}
The main purpose of this study was to check whether phyto- and endogenous estrogens influence calcium ion mobilization $\left[\mathrm{Ca}^{2+}\right]_{\mathrm{i}}$ in bovine endometrial cells and whether this action is connected with biological effects i.e. prostaglandin $(\mathrm{PG}) \mathrm{F}_{2 \alpha}$ production. In our study we used two calcium measurement methods by comparing the microscopic method with widely used quantitative - spectrofluorometric method of $\left[\mathrm{Ca}^{2+}\right]_{i}$ measurement. We also wanted to confirm whether visualization of calcium ion $\left[\mathrm{Ca}^{2+}\right]_{i}$ in cells using microscopic method supported by micro image analysis (Micro Image Olympus system) reflects real, qualitative changes in the ion concentration. In both methods a cell-permeable form of fluorescent $\left[\mathrm{Ca}^{2+}\right]_{i}$ indicator Fura- 2 was used. Cultured bovine endometrial epithelial and stromal cells influenced by phorbol-2-myristate-13-acetate (PMA; positive control), estradiol 17- $\beta$ ( $\mathrm{E}_{2}$; endogenous estrogen) and active metabolites of phytoestrogens (environmental estrogens) were used as a model to study $\mathrm{PGF}_{2 \alpha}$ secretion and $\left[\mathrm{Ca}^{2+}\right]_{\mathrm{i}}$ mobilization in the cells. Equol and para-ethyl-phenol in doses of $10^{-8}-10^{-6} \mathrm{M}$ increased $\mathrm{PGF}_{2 \alpha}$ concentration both in epithelial and stromal cells $(\mathrm{P}<0.05)$. In both methods, equol and para-ethyl-phenol did not cause intracellular $\left[\mathrm{Ca}^{2+}\right]_{i}$ mobilization in epithelial and stromal cells $(\mathrm{P}>0.05)$. Both methods revealed that only $\mathrm{E}_{2}$ and PMA induced intracellular $\left[\mathrm{Ca}^{2+}\right]_{i}$ mobilization in epithelial and stromal cells $(\mathrm{P}<0.05)$. The results of both methods were highly correlated $(\mathrm{P}<0.001 ; \mathrm{r}=0.82$ for epithelial cells and $\mathrm{r}=0.89$ for stromal cells). In conclusion, both methods gave approximately the same results and showed that phytoestrogens, in contrast to PMA and $E_{2}$, did not cause intracellular $\left[\mathrm{Ca}^{2+}\right]_{i}$ mobilization in endometrial cells. The obtained results proved that the $\left[\mathrm{Ca}^{2+}\right]_{i}$ visualization method supported by micro image analysis can produce similar results to the spectrofluorometric method.

Key words: Calcium measurement, Cattle, Endometrial cells, PGF $_{2 \alpha}$, Phytoestrogens
\end{abstract}

(J. Reprod. Dev. 52: 731-740, 2006)

D aidzein and genistein are two major phytoestrogens present in soybean [1-3]. In ruminants, rumen microorganisms convert

Accepted for publication: August 7, 2006

Published online: September 11, 2006

Correspondence: D. J. Skarzynski (e-mail: skadar@pan.olsztyn.pl) daidzein into equol, and genistein into para-ethylphenol (the two most active metabolites) [3, 4]. There is increasing evidence that phytoestrogens can disrupt reproductive processes in cows [3, 5-8]. In ruminants, endogenous estrogens are known to control the estrous cycle by influencing prostaglandin (PG) synthesis $[9,10]$. We have 
recently shown that soybean-derived phytoestrogens, like endogenous $E_{2}$, regulate both $\mathrm{PGE}_{2}$ and $\mathrm{PGF}_{2 \alpha}$ secretion in the endometrium during the estrous cycle and early pregnancy in cattle $[3,6,7]$. However, they preferentially stimulate luteolytic $\mathrm{PGF}_{2 \alpha}$ secretion from the bovine endometrium in vivo [3] and in vitro [6, 7]. Owing to phytoestrogen structural similarity to $E_{2}$, we suspect that they, acting as antagonists or agonists of endogenous estrogens, may disrupt numerous reproductive processes on several levels of regulation and via mechanisms similar or different to endogenous estrogen intracellular mechanisms.

In recent years many in vitro studies have examined the intracellular mechanisms of estrogenic substance actions on various target tissues. Endogenous estrogens exert their physiological effects in target cells by genomic [6, $11,12]$ and non-genomic pathways [13]. The genomic pathway is mainly based on estrogen binding to both estrogen receptor (ER) $\alpha$ and $\beta[11$, $12]$, whereas the non-genomic pathway is based on their influence on the action of the two most important compounds of the intracellular second messenger system:, protein kinase A (PKA) and phospholipase C (PLC), as well as intracellular calcium $\left[\mathrm{Ca}^{2+}\right]_{\mathrm{i}}$ mobilization [14-16]. Both, genomic and non-genomic mechanisms of endogenous and environmental estrogen action in various tissues including the bovine endometrium have been studied previously $[6,11,12]$.

Measurement of intracellular $\left[\mathrm{Ca}^{2+}\right]_{\mathrm{i}}$ mobilization is a useful parameter for investigating the intracellular mechanisms of the non-genomic action of various substances in cells. There is one well-known spectrofluorometric $\mathrm{Ca}^{2+}$ measurement system, which was first described by Grynkiewicz et al. [17], widely used by many researchers [18-20]. In our laboratory, we have recently established a method of $\left[\mathrm{Ca}^{2+}\right]_{\mathrm{i}}$ visualization in live cells using an inverted microscope with fluorescent supply (Micro Image Olympus system). However, it has not been established whether visualization of $\left[\mathrm{Ca}^{2+}\right]_{i}$ in cells using a microscopic method supported by micro image analysis (Micro Image Olympus system) reflects real, qualitative changes in ion concentrations. Therefore, common application of a new method concerning measurement of intracellular $\left[\mathrm{Ca}^{2+}\right]_{\mathrm{i}}$ mobilization requires comparison with the well-known, thoroughly described spectrofluorometric quantitative system [17-20]. Bearing the above in mind, the aim of this study was to check whether phyto- and endogenous estrogens influence $\left[\mathrm{Ca}^{2+}\right]_{i}$ in bovine endometrial cells and whether this action is connected with biological effect, such as $\mathrm{PGF}_{2 \alpha}$ production. In our study we used two $\left[\mathrm{Ca}^{2+}\right]_{\mathrm{i}}$ measurement methods by comparing microscopic method with the widely used quantitative spectrofluorometric method of $\left[\mathrm{Ca}^{2+}\right]_{i}$ measurement. We also wanted to confirm whether visualization of $\left[\mathrm{Ca}^{2+}\right]_{i}$ in cells using the microscopic method supported by micro image analysis (Micro Image lympus system) reflects real, qualitative changes in the ion concentration.

\section{Materials and Methods}

\section{Animals and collection of endometrial tissues}

Bovine uteri were obtained at a local abattoir within $30 \mathrm{~min}$ of exsanguination and were transported on ice to the laboratory within $1 \mathrm{~h}$. Early estrous cycle (2-5 days) uteri were used in this study [21]. Estimation of the stages of the estrous cycle was determined by macroscopic observation of the ovaries and uterus [22]. The uterine horns were separated from each other and from the remaining tissue.

\section{Isolation and culture of endometrial cells}

The epithelial and stromal cells from the bovine endometrium were enzymatically separated $(0.05 \%$ collagenase; Sigma Aldrich, St. Louis, MO, USA; \# C0130) using procedures described and well characterized previously $[6,7,21,23]$. Cell viability was higher than $85 \%$. The homogeneity of the cells and contamination of the stromal and epithelial cell cultures (with epithelial cells and stromal cells, respectively) were evaluated using immunofluorescent staining for specific markers of epithelial (cytokeratin) and stromal cells (vimentin) [23]. Each type of cells was separately seeded at a density of $1 \times 10^{5}$ viable cells $/ \mathrm{mL}$ in 48 -well plates (Preliminary Experiment; Nunc, Roskilde, Denmark, \#150687), $30 \mathrm{ml}$ bottles (Experiment 1; Sarstedt, \#83.1813.300), or 4-well plates (Experiment 2; Nunc, \#176740). The cells were cultured at $38.5 \mathrm{C}$ in a humidified atmosphere of $5 \% \mathrm{CO}_{2}$ in $95 \%$ air.

To determine whether different doses of 
phytoestrogen metabolites influence $\mathrm{PGF}_{2 \alpha}$ synthesis in bovine endometrial epithelial and stromal cells and to compare the two intracellular $\left[\mathrm{Ca}^{2+}\right]_{\mathrm{i}}$ measurement methods, the cells were stimulated simultaneously with various reagents as described below.

Preliminary experiment: The aim of this experiment was to choose the most effective dose of phytoestrogen metabolites for $\mathrm{PGF}_{2 \alpha}$ production in cultured bovine endometrial epithelial and stromal cells. When confluence was reached (5-6 days of culture), the epithelial and stromal cells were treated for $24 \mathrm{~h}$ with various concentrations $\left(10^{-6} \mathrm{M}\right.$ to $10^{-10} \mathrm{M}$ ) of the following phytoestrogen metabolites: equol (Fluka Chemie $\mathrm{GmbH}, 30918$ Seelze, Germany, \#45405) and para-ethyl-phenol (Merck \& Co., Inc., NJ, USA, \# 821290). Estradiol$17 \beta$ (Fluka, \#75262; $10^{-9} \mathrm{M}$ ) was used as a reference compound. Tumor necrosis factor- $\alpha$ (TNF $\alpha$; Dainippon Pharmaceutical Co. Ltd., Osaka, Japan; $6 \times 10^{-11} \mathrm{M}$ ) and oxytocin (OT; Sigma, \#O4375; $10^{-7}$ $\mathrm{M})$ were used as positive controls for stromal and epithelial cells, respectively [21, 22]. After $24 \mathrm{~h}$ incubation, the conditioned media were collected in tubes with $10 \mu \mathrm{L}$ EDTA and 1\% aspirin (Sigma; \#A2093) solution ( $\mathrm{pH} 7.3$ ), and frozen at -20 C until measurement of $\mathrm{PGF}_{2 \alpha}$. The conditioned media were examined for the concentrations of $\mathrm{PGF}_{2 \alpha}$ by EIA as described previously [22]. The $\mathrm{PGF}_{2 \alpha}$ standard curve ranged from $0.016 \mathrm{ng} / \mathrm{mL}$ to $4 \mathrm{ng} /$ $\mathrm{mL}$, and the $\mathrm{ED}_{50}$ of the assay was $0.25 \mathrm{ng} / \mathrm{mL}$. The mean intra- and interassay coefficients of variation were $11.3 \%(n=10)$ and $7.1 \%(n=10)$, respectively.

Experiment 1: Intracellular $\left[\mathrm{Ca}^{2+}\right]_{\mathrm{i}}$ mobilization was measured in millisecond intervals for 60 seconds by a quantitive method described by Skarzynski and Okuda [20]. In this method Fura-2, a cell-permeable form of the fluorescent $\left[\mathrm{Ca}^{2+}\right]_{i}$ indicator, was used. Epithelial and stromal endometrial cells were trypsinised from the bottles [23] and suspended in calcium-free HBSS supplemented with $0.1 \%$ BSA. After that, the cells were washed three times by centrifugation in calcium-free HBSS (5 min; $100 \times$ G). Fura-2 AM, the lipophilic acetoxymethyl ester form of Fura-2, was dissolved in DMSO to form a $1 \mathrm{mM}$ stock solution; and $10 \mu \mathrm{l}$ was added to $2-\mathrm{ml}$ cell suspensions (final concentration: $5 \mu \mathrm{M}$ ) to preload the cells with dye. The cells were incubated for $30 \mathrm{~min}$ at $37 \mathrm{C}$ and then washed 3 times in calcium-free HBSS. After washing, the cells were postincubated for $30 \mathrm{~min}$ in
HBSS at room temperature to ensure full hydrolysis of the Fura-2 ester. Spectrofluorometric measurements were conducted in 1.5-ml samples continuously stirred in a quartz-glass cuvette and thermostatically maintained at $37 \mathrm{C}$. Fluorescence was monitored using a Shimadzu spectrofluorometer RF-5000 (Shimadzu, Kyoto, Japan). The intensity of fluorescence was measured in milisecond intervals for 60 seconds in cells treated with equol $\left(10^{-8} \mathrm{M}\right)$ or para-ethyl-phenol $\left(10^{-8} \mathrm{M}\right)$ in the $25^{\text {th }}$ second of the experiment. All phytoestrogen doses were based on previous studies [3, 6, 7]. Estradiol- $17 \beta\left(10^{-9} \mathrm{M}\right)$ was used as a reference compound ( $25 \mathrm{th}$ second of the experiment). The excitation and emission wavelengths were $340 \mathrm{~nm}$ and $490 \mathrm{~nm}$, respectively, with slit widths of $5 \mathrm{~nm}$ for both wavelengths. The intracellular $\left[\mathrm{Ca}^{2+}\right]_{\mathrm{i}}$ concentrations were calculated using the following equation:

$$
\left[\mathrm{Ca}^{2+}\right]_{\mathrm{i}}=\mathrm{KD} \times\left[\left(\mathrm{F}-\mathrm{F}_{\min }\right) /\left(\mathrm{F}_{\max }-\mathrm{F}\right)\right],
$$

where $\mathrm{F}$ is the fluorescence in the examined sample and the KD of Fura-2 is 224 at $37.5 \mathrm{C}$.

Maximum fluorescence $\left(\mathrm{F}_{\max }\right)$ was measured by maximum mobilization of the Fura-2-Ca ${ }^{2+}$ complex with PMA (Phorbol 12-myristate 13-acetate; Sigma, \# P148; $10^{-7}$ M) [24].

Experiment 2: When the epithelial and stromal cells reached $50-75 \%$ confluence (3-4 days of culture), the medium was changed and the cells were washed 3 times with calcium-free HBSS. Fura-2 AM, the lipophilic acetoxymethyl ester form of Fura-2, was dissolved in DMSO to form a $1 \mathrm{mM}$ stock solution, and $10 \mu \mathrm{l}$ was added to each culture well (final concentration: $5 \mu \mathrm{M}$ ) to preload the cells with dye. The cells were incubated at $37 \mathrm{C}$ for 40 min and then washed 4 times in calcium free HBSS. Cells were then incubated in calcium-free HBSS supplemented with $0.1 \%$ BSA for $30 \mathrm{~min}$ at $37 \mathrm{C}$ to allow hydrolysis of cytoplasmic Fura-2. The cells were then washed 3 times in calcium-free HBSS. Changes in the intracellular concentrations of $\left[\mathrm{Ca}^{2+}\right]_{i}$ were monitored using an inverted microscope equipped with a fluorescent lamp and a Fura-2 filter. The intensity of fluorescence and the area occupied by the fluoresceing cells were measured every $5 \mathrm{sec}$ from 25 seconds before through 35 seconds after treatment with: equol $\left(10^{-8}\right.$ $\mathrm{M})$ or p-ethyl-phenol $\left(10^{-8} \mathrm{M}\right)$. Estradiol- $17 \beta\left(10^{-9} \mathrm{M}\right)$ 
was used as reference compound $\left(25^{\text {th }}\right.$ second of the experiment). Phorbol myristate acetate (PMA; $10^{-7}$ M) was used as a positive control of $\left[\mathrm{Ca}^{2+}\right]_{i}$ exflux for both types of cells $\left(50^{\text {th }}\right.$ second of the experiment). Intracellular $\left[\mathrm{Ca}^{2+}\right]_{i}$ mobilization was measured by $\left[\mathrm{Ca}^{2+}\right]_{\mathrm{i}}$ visualization, every 5 seconds for 60 seconds. Digital interpretation for the computer-supported $\left[\mathrm{Ca}^{2+}\right]_{\mathrm{i}}$ visualization method was obtained using the density green and density mean of the examined cells in each separate photograph. Changes in intracellular $\left[\mathrm{Ca}^{2+}\right]_{i}$ concentrations following treatments were shown on a graph as arbitrary units of intensity as analyzed by the computer software (Micro Image 4.0; Olympus Optical Co., Hamburg, Germany).

\section{Statistical analysis}

The data are shown as the mean \pm SEM of values obtained in three separate experiments, each performed in triplicate. The statistical significance of differences between selected data sets was assessed by Student's t-test (GraphPad Prism version 4; GraphPad Software, Inc., San Diego, CA). Pearson's correlation coefficient was calculated (GraphPad Prism) for the $\left[\mathrm{Ca}^{2+}\right]_{\mathrm{i}}$ data measured by the two methods after treatment of the cells with the estrogenic reagents and PMA.

\section{Results}

\section{Preliminary experiment. Determination of the effective dose of phytoestrogen metabolites}

Both phytoestrogen metabolites (equol and paraethyl-phenol) stimulated $\mathrm{PGF}_{2 \alpha}$ secretion in a dosedependent manner in the epithelial and stromal cells $(\mathrm{P}<0.05)$. Figure 1 shows $\mathrm{PGF}_{2 \alpha}$ production by epithelial cells in response to equol (a), para-ethylphenol (b), $E_{2}$, and OT. Estradiol-17 $\beta$ at a concentration of $10^{-9} \mathrm{M}$ stimulated $\mathrm{PGF}_{2 \alpha}$ secretion in epithelial cells $(2.24 \pm 0.5$-fold; $\mathrm{P}<0.05)$. Equol in all used doses stimulated $\mathrm{PGF}_{2 \alpha}$ secretion in epithelial cells compared with the control $(\mathrm{P}<0.01)$. The most statistically significant stimulatory effect of equol was observed at a dose of $10^{-8} \mathrm{M}(6.08 \pm 1.4$ fold of stimulation compared to the control; $\mathrm{P}<0.001)$. Para-ethyl-phenol stimulated $\mathrm{PGF}_{2 \alpha}$ secretion in epithelial cells at all doses compared with the controls $(\mathrm{P}<0.05)$. The most statistically significant stimulatory effect of para-ethyl-phenol was observed at a dose of $10^{-8} \mathrm{M}(4.43 \pm 0.4$ fold of

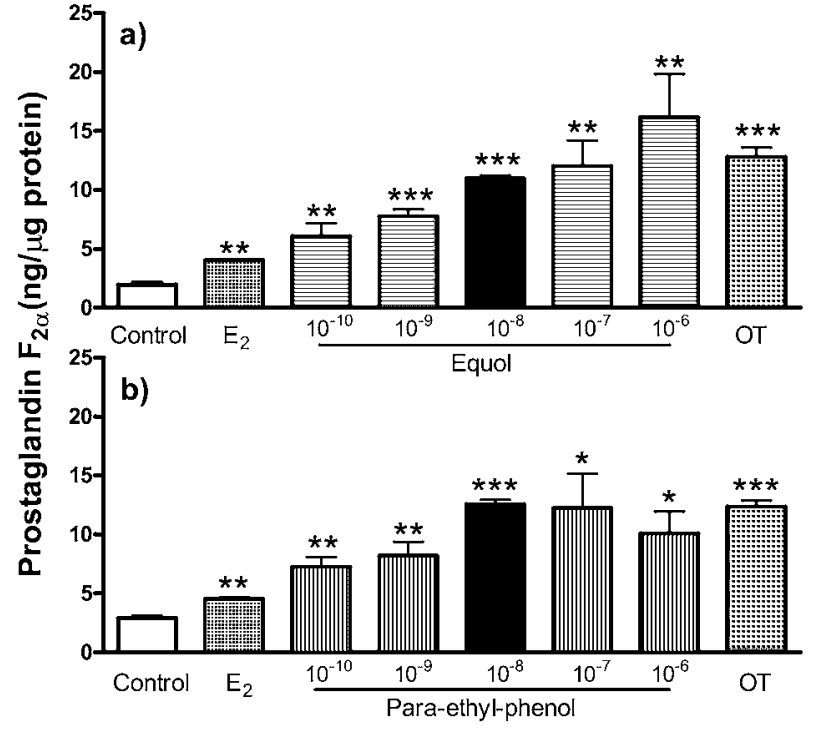

Fig. 1. Effects of various concentrations $\left(10^{-10}-10^{-6} \mathrm{M}\right)$ of phytoestrogen metabolites on $\mathrm{PGF}_{2 \alpha}$ production by bovine endometrial epithelial cells. Equol (a), p-ethylphenol (b), estradiol- $17 \beta\left(\mathrm{E}_{2} ; 10^{-9} \mathrm{M}\right)$, or OT $\left(10^{-7} \mathrm{M}\right)$ were added to the medium for $24 \mathrm{~h}$. Asterisks indicate significant differences between control and treated groups $\left({ }^{*} \mathrm{P}<0.05 ;{ }^{* *} \mathrm{P}<0.01 ;{ }^{* *} \mathrm{P}<0.001\right)$, as determined by Student's t- test.

stimulation compared to the control; $\mathrm{P}<0.001)$. OT $\left(10^{-7} \mathrm{M}\right)$ stimulated $\mathrm{PGF}_{2 \alpha}$ secretion in epithelial cells $(4.47 \pm 0.8-$ fold; $P>0.05)$ compared with the controls, showing the physiological properties of the cultured cells during the experiment.

Estradiol $17 \beta$ at a concentration of $10^{-9} \mathrm{M}$ did not stimulate $\mathrm{PGF}_{2 \alpha}$ secretion in stromal cells $(\mathrm{P}>0.05)$. Both phytoestrogen metabolites stimulated $\mathrm{PGF}_{2 \alpha}$ secretion in stromal cells at all doses compared with the controls $(\mathrm{P}<0.05$; data not shown). Paraethyl-phenol and equol at a dose of $10^{-8} \mathrm{M}$ stimulated $\mathrm{PGF}_{2 \alpha}$ secretion in stromal cells with the highest statistical significance ( $2.8 \pm 0.1$ and $2.6 \pm 0.1$ fold of the control, respectively; $\mathrm{P}<0.001)$. TNF $\alpha$ (6 $\left.\times 10^{-11} \mathrm{M}\right)$ stimulated $\mathrm{PGF}_{2 \alpha}$ secretion in stromal cells $(4.0 \pm 0.3$-fold; $\mathrm{P}<0.001)$ compared with the controls, showing physiological properties of the cultured cells during the experiment.

The concentration of both phytoestrogen metabolites that gave the most significant increase in $\mathrm{PGF}_{2 \alpha}$ secretion in epithelial and stromal cells $(\mathrm{P}<0.001)$ was $10^{-8} \mathrm{M}$. Therefore, a concentration of $10^{-8} \mathrm{M}$ was chosen for further experiments. 
a)
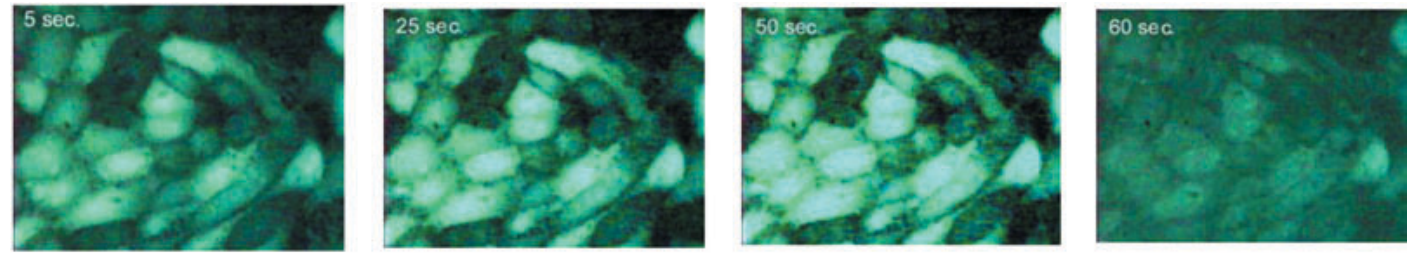

b)
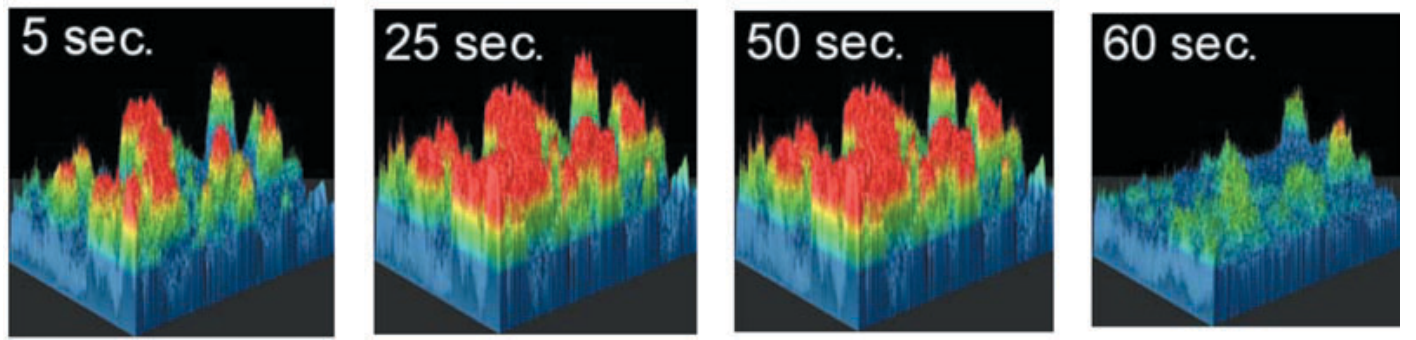

c)

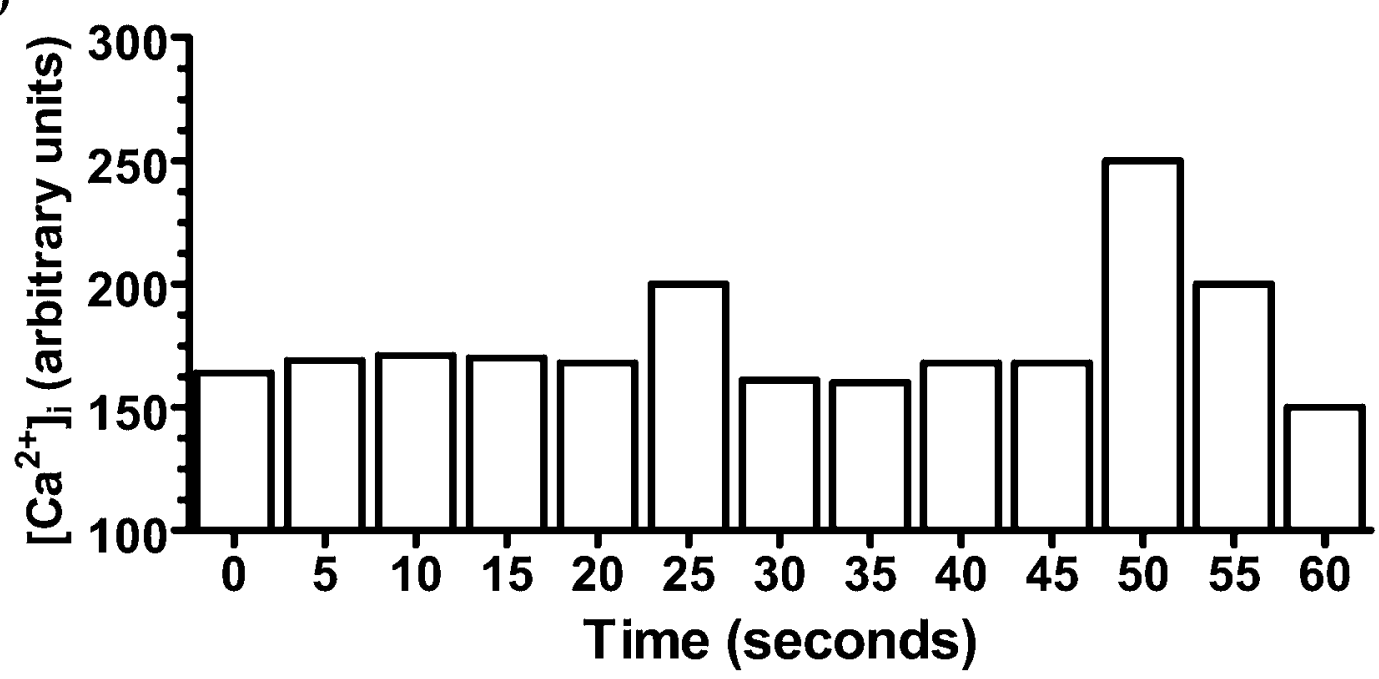

Fig. 2. Effects of estradiol- $17 \beta\left(\mathrm{E}_{2}\right)$ and PMA (control) on $\left[\mathrm{Ca}^{2+}\right]_{i}$ in epithelial cells during 60 seconds of the experiment. Panel (a): photographs of the cells at the $5^{\text {th }}$ (control), $25^{\text {th }}\left(\mathrm{E}_{2}\right.$ treatment; $\left.10^{-9} \mathrm{M}\right), 50^{\text {th }}$ (PMA treatment; $\left.10^{-7} \mathrm{M}\right)$, and $60^{\text {th }}$ second of one representative experiment (end of the experiment). Similar profiles were obtained in 3 other experiments. Panel (b): graphic analysis of the changes of fluorescence of the cells from panel (a). Panel (c): digital interpretation of the intracellular $\left[\mathrm{Ca}^{2+}\right]_{\mathrm{i}}$ mobilization in epithelial cells measured by the computer-supported $\left[\mathrm{Ca}^{2+}\right]_{\mathrm{i}}$ visualization method (Micro Image 4.0).

Effects of $E_{2}$, Phorbol 12-myristate 13-acetate, and phytoestrogen metabolites on intracellular $\mathrm{Ca}^{2+}$ mobilization in epithelial cells

Graphical and digital interpretation of the influence of equol $\left(10^{-8} \mathrm{M}\right)$ at the $25^{\text {th }}$ second and PMA $\left(10^{-7} \mathrm{M}\right)$ at the $50^{\text {th }}$ second of one representative experiment on the concentrations of $\left[\mathrm{Ca}^{2+}\right]_{\mathrm{i}}$ in the epithelial cells of the bovine endometrium are presented in Fig. 2. The changes in the intracellular $\left[\mathrm{Ca}^{2+}\right]_{i}$ concentrations following the treatments are shown on the graph as arbitrary units of intensity as analyzed by Micro Image 4.0.

Figure 3 shows the intracellular $\left[\mathrm{Ca}^{2+}\right]_{i}$ mobilization of epithelial cells measured by the spectrofluorometric method on the left panel and micro image analysis of $\left[\mathrm{Ca}^{2+}\right]_{\mathrm{i}}$ visualization of the cells on the right panel. The spectrofluorometric method revealed that neither equol nor para-ethylphenol $\left(10^{-8} \mathrm{M}\right.$ both) caused intracellular $\left[\mathrm{Ca}^{2+}\right]_{\mathrm{i}}$ mobilization in epithelial cells ( $\mathrm{P}>0.05$; Fig. $3 \mathrm{a}, \mathrm{b}$ ). In the micro image analysis $\left[\mathrm{Ca}^{2+}\right]_{\mathrm{i}}$ visualization method, equol and para-ethyl-phenol did not cause 

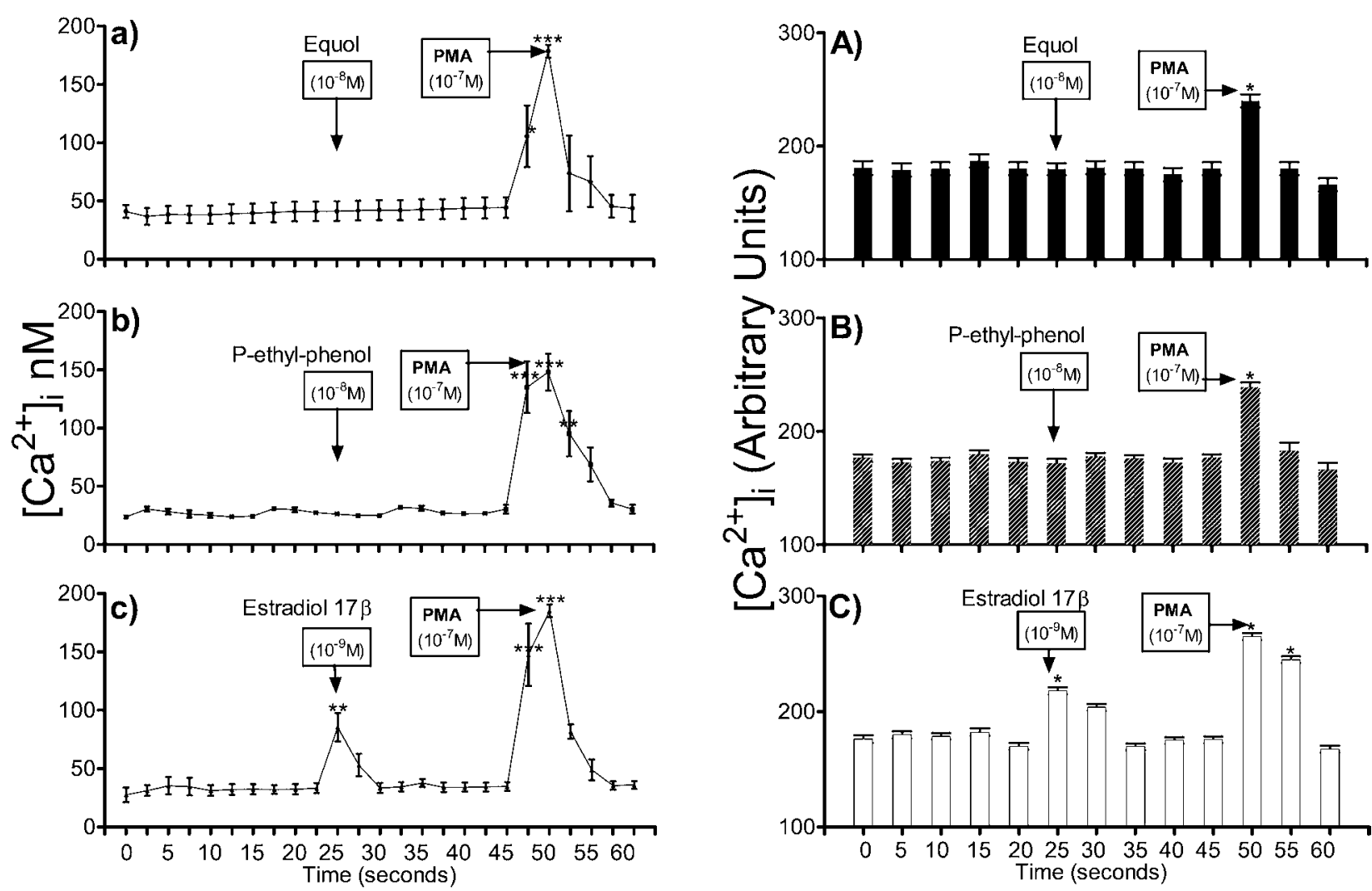

Fig. 3. Digital interpretation of the intracellular $\left[\mathrm{Ca}^{2+}\right]_{i}$ mobilization in epithelial cells measured by the spectrofluorometric method on the left panel and the computer-supported $\left[\mathrm{Ca}^{2+}\right]_{i}$ visualization method on the right panel. Influence of equol $\left(10^{-8} \mathrm{M}\right)(\mathrm{a}, \mathrm{A})$, para-ethyl-phenol $\left(10^{-8} \mathrm{M}\right)(\mathrm{b}, \mathrm{B})$, and estradiol- $17 \beta\left(\mathrm{E}_{2} ; 10^{-9} \mathrm{M}\right)(\mathrm{c}, \mathrm{C})$ on the concentrations of intracellular calcium in the epithelial cells of the bovine endometrium. The changes in calcium concentrations are shown as changes in the fluorescence of $\left[\mathrm{Ca}^{2+}\right]_{i}$-FURA 2-AM complex. Digital interpretation from the computer-supported $\left[\mathrm{Ca}^{2+}\right]_{\mathrm{i}}$ visualization method was obtained using the density green and density mean of the cells examined with Micro Image 4.0. The results were shown on the graph as arbitrary units of intensity. Asterisks indicate significant differences between control and treated groups $\left({ }^{* * *} \mathrm{P}<0.001 ;{ }^{* *} \mathrm{P}<0.01 ;{ }^{*} \mathrm{P}<0.05\right)$, as determined by one-way ANOVA followed by Bonfferoni's multiple comparison test $(n=4)$.

intracellular $\left[\mathrm{Ca}^{2+}\right]_{\mathrm{i}}$ mobilization in epithelial cells either ( $\mathrm{P}>0.05$; Fig. $3 \mathrm{~A}, \mathrm{~B})$. Both methods revealed that only $\mathrm{E}_{2}\left(10^{-9} \mathrm{M}\right)$ caused intracellular $\mathrm{Ca}^{2+}$ mobilization in epithelial cells $(\mathrm{P}<0.05$; Fig. $3 \mathrm{c}, \mathrm{C})$. Phorbol 12-myristate 13-acetate (PMA; $10^{-7} \mathrm{M}$ ) induced intracellular $\mathrm{Ca}^{2+}$ mobilization in epithelial cells $(\mathrm{P}<0.05)$, which accounts for the appropriate responsiveness of the cells. The results for both methods were highly correlated $(\mathrm{P}<0.001 ; \mathrm{r}=0.82)$.

Effects of $E_{2}$, phorbol 12-myristate 13-acetate, and phytoestrogen metabolites on intracellular $\mathrm{Ca}^{2+}$ mobilization in stromal cells

Figure 4 shows the intracellular $\left[\mathrm{Ca}^{2+}\right]_{i}$ mobilization in stromal cells measured by the spectrofluorometric method on the left panel and micro image analysis of $\left[\mathrm{Ca}^{2+}\right]_{i}$ visualization of the cells on the right panel. The spectrofluorometric method revealed that neither equol nor para-ethylphenol $\left(10^{-8} \mathrm{M}\right.$ both) caused intracellular $\left[\mathrm{Ca}^{2+}\right]_{\mathrm{i}}$ mobilization in stromal cells ( $\mathrm{P}>0.05$; Fig. $4 \mathrm{a}, \mathrm{b})$. In the micro image analysis $\left[\mathrm{Ca}^{2+}\right]_{i}$ visualization method equol and para-ethyl-phenol did not cause intracellular $\left[\mathrm{Ca}^{2+}\right]_{i}$ mobilization in stromal cells either ( $>0.05$; Fig. 4 A, B). Both methods revealed that only $\mathrm{E}_{2}\left(10^{-9} \mathrm{M}\right)$ caused intracellular $\mathrm{Ca}^{2+}$ mobilization in stromal cell ( $\mathrm{P}<0.05$; Fig. $4 \mathrm{c}, \mathrm{C})$. Phorbol 12-myristate 13-acetate (PMA; $10^{-7} \mathrm{M}$ ) induced the intracellular $\left[\mathrm{Ca}^{2+}\right]_{\mathrm{i}}$ mobilization in stromal cells $(\mathrm{P}<0.05)$, which accounts for the 

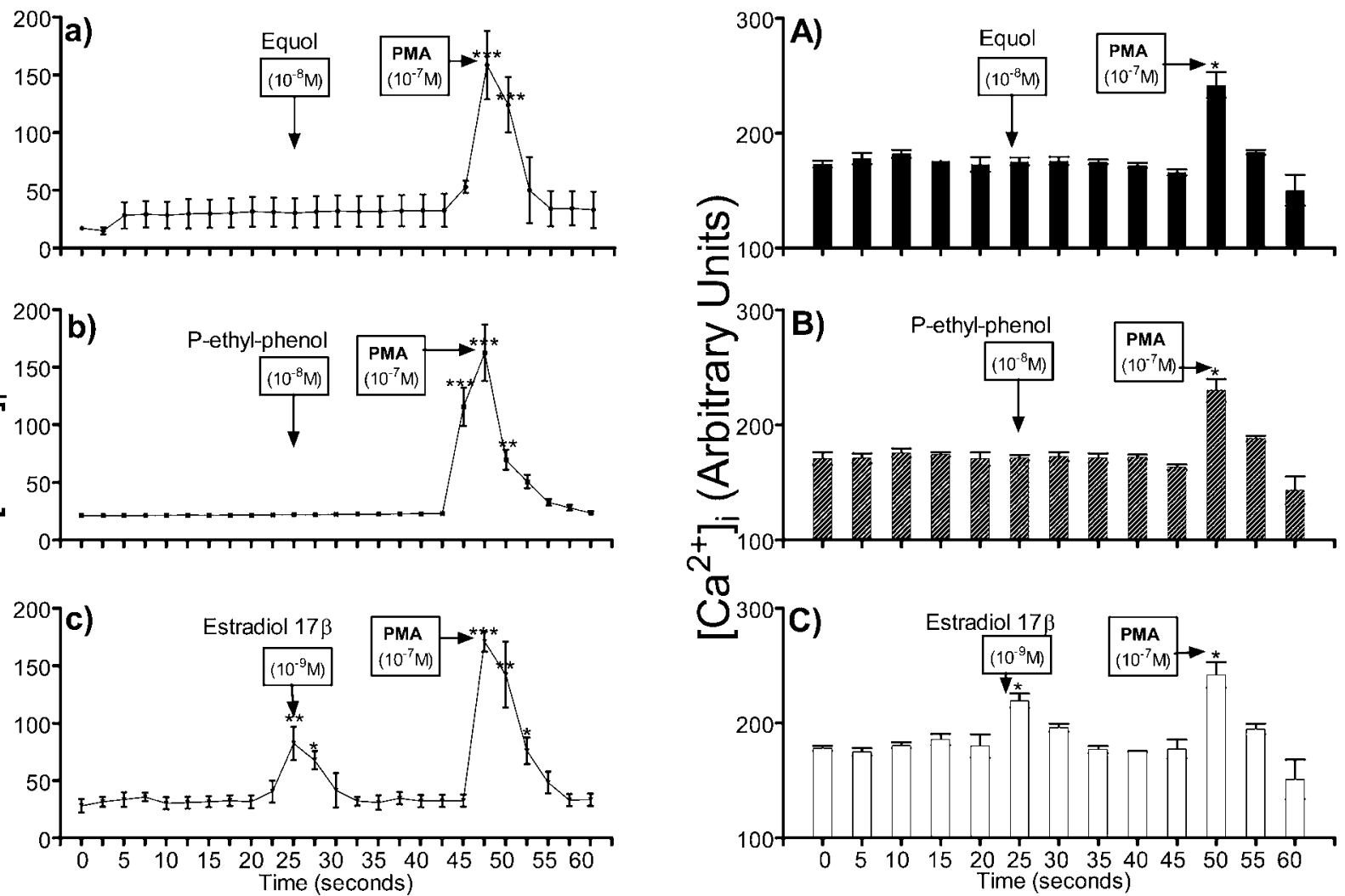

Fig. 4. Digital interpretation of the intracellular $\left[\mathrm{Ca}^{2+}\right]_{i}$ mobilization in stromal cells measured by the spectrofluorometric method on the left panel and computer-supported $\left[\mathrm{Ca}^{2+}\right]_{\mathrm{i}}$ visualization method on the right panel. Influence of equol $\left(10^{-8} \mathrm{M}\right)(\mathrm{a}, \mathrm{A})$, para-ethyl-phenol $\left(10^{-8} \mathrm{M}\right)(\mathrm{b}, \mathrm{B})$, and $\mathrm{E}_{2}\left(10^{-9} \mathrm{M}\right)(\mathrm{c}, \mathrm{C})$ on the concentrations of intracellular calcium in the stromal cells of the bovine endometrium. The changes in calcium concentrations are shown as changes in the fluorescence of $\mathrm{Ca}^{2+}$-FURA 2-AM complex. Digital interpretation from the computer-supported $\left[\mathrm{Ca}^{2+}\right]_{i}$ visualization method was obtained using the density green and density mean of the cells examined with Micro Image 4.0. The results are shown on the graph as arbitrary units of the intensity. Asterisks indicate significant differences between control and treated groups $\left({ }^{* * *} \mathrm{P}<0.001 ;{ }^{* *} \mathrm{P}<0.01 ;{ }^{*} \mathrm{P}<0.05\right)$, as determined by one-way ANOVA followed by Bonfferoni's multiple comparison test $(n=4)$.

appropriate responsiveness of the cells. The results for both methods were highly correlated $(\mathrm{P}<0.001$; $\mathrm{r}=0.89$ ).

\section{Discussion}

Equol and para-ethyl-phenol are two most active, soy bean-derived phytoestrogen metabolites [1-3]. We have recently shown that these phytoestrogen metabolites, like endogenous $E_{2}[10]$, regulate both $\mathrm{PGE}_{2}$ and $\mathrm{PGF}_{2 \alpha}$ secretion in the endometrium via different intracellular mechanisms in cattle [6]. However, the dose-dependent effect of phytoestrogen metabolites has not been previously studied separately in the epithelial and stromal cells of the bovine endometrium. Epithelial cells from the bovine endometrium are responsible for $\mathrm{PGF}_{2 \alpha}$ synthesis, whereas stromal cells synthesize approximately 10 times more luteotropic $\mathrm{PGE}_{2}$ than epithelial cells [21, 25, present data]. Thus, present and previous data suggest that in the bovine endometrium, epithelial cells are the target cells for $\mathrm{PGF}_{2 \alpha}$ synthesis concerning phytoestrogen metabolite action. Recently, we have also studied the effect of phytoestrogen metabolites on the steroidogenic cells of the bovine CL [8]. In steroidogenic CL cells phytoestrogen metabolites stimulated the production of two luteolytic substances, $\mathrm{PGF}_{2 \alpha}$ and testosterone [8]. Surprisingly, the most effective dose of phytoestrogen metabolites in terms of action on 
$\mathrm{PGF}_{2 \alpha}$ was $10^{-8} \mathrm{M}$ for both endometrial (present data) and steroidogenic cells [8], which is very similar to the concentrations of phytoestrogen metabolites in the blood plasma of cows fed estrogenic silage as reported by us $[3,8]$ and other researchers $[1,4]$.

In recent years, many in vitro studies have examined the intracellular mechanisms of estrogenic substance actions on various target tissues. Endogenous estrogens exert their physiological effects in target cells by genomic [6, $11,12]$ and non-genomic pathways [13]. Intracellular $\left[\mathrm{Ca}^{2+}\right]_{i}$ mobilization is one the most important compounds of the intracellular second messenger system in the non-genomic pathway of estrogen action [26-28]. Morley et al. [14], Katzenellenbogen [15], and Smith [16] proved that endogenous $\mathrm{E}_{2}$ can act via a non-genomic way, especially via intracellular $\left[\mathrm{Ca}^{2+}\right]_{i}$ mobilization. The results of the present study agree with findings of these research groups. In our study, only endogenous $E_{2}$, in contrast to phytoestrogen metabolites, caused intracellular $\left[\mathrm{Ca}^{2+}\right]_{i}$ mobilization in epithelial and stromal cells. These results suggest the lack of a non-genomic mechanism of phytoestrogen metabolite action in the bovine endometrium, in contrast to endogenous $E_{2}$.

In our study, we compared two different $\left[\mathrm{Ca}^{2+}\right]_{i}$ measurement systems using PMA as an internal control for ion mobilization. The increase of intracellular $\left[\mathrm{Ca}^{2+}\right]_{\mathrm{i}}$ mobilization in the cells in response to PMA accounts for the appropriate responsiveness of the cells [24]. In our study, both methods showed that PMA significantly increased intracellular $\left[\mathrm{Ca}^{2+}\right]_{i}$ mobilization in both the epithelial and stromal cells of the bovine endometrium. However, in the spectrofluorometric method, $\left[\mathrm{Ca}^{2+}\right]_{i}$ mobilization increased 6 times, from $26.6 \pm 5.2 \mathrm{nM}$ before treatment to 156.6 $\pm 6.9 \mathrm{nM}$ in PMA-treated epithelial cells. Using the micro image analysis $\left[\mathrm{Ca}^{2+}\right]_{\mathrm{i}}$ visualization method, $\left[\mathrm{Ca}^{2+}\right]_{\mathrm{i}}$ mobilization increased 1.6 times, from $160 \pm$ 9 arbitrary units before treatment to $256 \pm 16.5$ arbitrary units in PMA-treated epithelial cells. In stromal cells, we got similar results. In the spectrofluorometric method, $\left[\mathrm{Ca}^{2+}\right]_{i}$ mobilization increased 7.25 times (from $21.6 \pm 4.2 \mathrm{nM}$ to $156.6 \pm$ $15.6 \mathrm{nM}$ in PMA-treated cells), whereas in the micro image analysis $\left[\mathrm{Ca}^{2+}\right]_{i}$ visualization system, $\left[\mathrm{Ca}^{2+}\right]_{i}$ mobilization increased 1.40 times (from $176 \pm 3$ arbitrary units to $248 \pm 5$ arbitrary units in PMAtreated cells). Moreover, in both methods, endogenous $\mathrm{E}_{2}$ significantly increased $\left[\mathrm{Ca}^{2+}\right]_{i}$ mobilization in epithelial and stromal cells. However, in the spetrofluorometric method, $\left[\mathrm{Ca}^{2+}\right]_{i}$ mobilization was 7.1 times higher in epithelial cells and 6.4 times higher in stromal cells, whereas in the $\left[\mathrm{Ca}^{2+}\right]_{\mathrm{i}}$ visualization system it was 1.4 times higher in epithelial cells and 1.3 times higher in stromal cells. The above findings suggest that the spectrofluorometric method is much more precise in comparison to the $\left[\mathrm{Ca}^{2+}\right]_{\mathrm{i}}$ visualization method.

On the other hand, using the micro image analysis $\left[\mathrm{Ca}^{2+}\right]_{i}$ visualization system also has big advantages. It gives much more spectacular results. You can visualize each separate cell or a group of cells (Fig. 2). Moreover, using this method enables a researcher to observe, save and then analyze intracellular $\left[\mathrm{Ca}^{2+}\right]_{\mathrm{i}}$ mobilization in every separate cell and all cells together from the area of interest. You can take as many pictures as you need and for as long as you need. The other big advantage of this method is the ability to conduct a digital interpretation of images. Digital interpretation of images helps the reader thoroughly understand the changes in intracellular $\left[\mathrm{Ca}^{2+}\right]_{\mathrm{i}}$ mobilization in examined cells and may reflect real, qualitative changes in the ion concentrations.

In conclusion, phytoestrogen metabolites, in contrast to PMA and $E_{2}$, did not cause intracellular $\left[\mathrm{Ca}^{2+}\right]_{i}$ mobilization in the endometrial cells. However, both exogenous (phytoestrogenes) and endogenous $\left(E_{2}\right)$ estrogens stimulated $\mathrm{PGF}_{2 \alpha}$ production. Moreover, the present study demonstrates that the micro image analysis $\left[\mathrm{Ca}^{2+}\right]$ visualization method can produce similar results to the spectrofluorometric method. Even though both methods gave approximately the same results, the fluorescent method turned out to be quantitive and gave much more precise results in comparison to $\left[\mathrm{Ca}^{2+}\right]_{\mathrm{i}}$ visualization using an inverted microscope with fluorescent supply and micro image analysis. On the other hand, the ion visualization method can be considered a very good tool for examination of the dynamics of $\left[\mathrm{Ca}^{2+}\right]_{i}$ mobilization in each separate cell and for verification of the results obtained by the fluorescent method. 


\section{Acknowledgments}

This research was supported by Grants-in-Aid for Scientific Research from the Polish Ministry of Scientific Research and Information Technology (KBN 2P06K 003 30) and the Japan Society for the
Promotion of Science (JSPS: 18380166) and by Olympus Poland. DJS was supported by the Japanese Society for Promotion of Sciences Invitation Fellowship Program for Research in Japan for Senior Scientists (Long-Term; L-05569).

\section{References}

1. Lundh TJ-O, Pettersson H, Kiessling KH. Liquid chromatographic determination of the estrogens daizein, formononentin, coumestrol and equol in bovine blood plasma and urine. J Assoc Off Anal Chem 1988; 71: 938-942.

2. Baker ME. Flavonoids as hormone. Flavonoids living system, a perspective from an analysis of molecular fossils. Adv Exp Med Biol 1998; 439: 249267.

3. Woclawek-Potocka I, Bah MM, Korzekwa A, Piskula M, Wiczkowski W, Depta A, Skarzynski DJ. Soy-bean derived phytoestrogens regulate prostaglandin secretion in endometrium during the estrous cycle and early pregnancy in cattle. Exp Biol Med 2005; 230: 189-199.

4. Lundh TJ-O, Pettersson H, Marinsson KA. Comparative levels of free and conjugated plant estrogens in blood plasma and cattle fed estrogenic silage. J Agric Food Chem 1990; 38: 1530-1534.

5. Reinhart KC, Dubey RK, Keller PJ, Roselli M. Xenoestrogens and phytoestrogens induce the synthesis of leukemia inhibitory factor by human and bovine oviduct cells. Mol Hum Reprod 1999; 5: 899-907.

6. Woclawek-Potocka I, Acosta TJ, Korzekwa A, Bah MM, Shibaya M, Okuda K, Skarzynski DJ. Phytoestrogens modulate prostaglandin production in bovine endometrium: cell type specifity and intracellular mechanisms. Exp Biol Med 2005; 230: 326-333.

7. Woclawek-Potocka I, Okuda K, Acosta TJ, Korzekwa A, Pilawski W, Skarzynski DJ. Phytoestrogen metabolites are much more active than phytoestrogens themselves in increasing prostaglandin $F_{2 \alpha}$ synthesis via prostaglandin $F_{2 \alpha}$ synthase-like 2 stimulation in bovine endometrium. Prostaglandins Other Lipid Mediat 2005; 78: 202-217.

8. Piotrowska K, Woclawek-Potocka I, Bah MM, Piskula M, Pilawski W, Bober A, Skarzynski DJ. Phytoestrogens and their metabolites inhibit the sensitivity of the bovine corpus luteum on luteotropic factors. J Reprod Dev 2006; 52: 33-41.

9. Sugino N, Karuba-Karada A, Taketani T, Sakata A, Nakamura Y. Withdrawal of ovarian steroids stimulates prostaglandin $\mathrm{F}_{2 \alpha}$ production through nuclear factor- $\kappa \mathrm{B}$ activation via oxygen radicals in human endometrial stromal cells: potential relevance to menstruation. J Reprod Dev 2004; 50: 215-225.

10. Goff AK. Steroid hormone modulation of prostaglandin secretion in the ruminant endometrium during the estrous cycle. Biol Reprod 2004; 71: 11-16.

11. Wang C, Sathyamoorthy N, Phang JM. Molecular effects of genistein on receptor mediated pathways. Carcinogen 1996; 17: 271-275.

12. Wang C, Kurzer MS. Effects of phytoestrogens on DNA synthesis in MCF-7 cells in the presence of estradiol or growth factors. Nur Cancer 1998; 3: 90100.

13. Losel RM, Falkenstein E, Feuring M, Schultz A, Tillmann HC, Rossol-Haseroth K, Wehling M. Nongenomic steroid action: controversies, questions, and answers. Physiol Rev 2003; 83: 9651016.

14. Morley P, Whitfield JF, Vanderhygen BC, Tsang BK, Schwarz JL. A new, nongenomic estrogen action: the rapid release of intracellular calcium. Endocrinology 1992; 131:1305-1312.

15. Katzenellenbogen BS. Estrogen receptor: bioactivities and interactions with cell signaling pathways. Biol Reprod 1996; 54: 287-293.

16. Smith CL. Cross-talk between peptide growth factor and estrogen receptor signaling pathways. Biol Reprod 1998; 58: 627-632.

17. Grynkiewicz G, Poenie M, Tsien RY. A new generation of $\mathrm{Ca}^{2+}$ indicators with greatly improved fluorescence properties. J Biol Chem 1985; 260: 34403450 .

18. Uto A, Arai H, Ogawa Y. Reassessment of Fura-2 and the ratio method for determination of intracellular $\mathrm{Ca}^{2+}$ concentrations. Cell Calcium 1991; 12: 324 .

19. Neher E. The use of fura-2 for estimating Ca buffers and Ca fluxes. Neuropharmacology 1995; 34: 14231442.

20. Skarzynski DJ, Okuda K. Sensitivity of bovine corpora lutea to $\mathrm{PGF}_{2 \alpha}$ is dependent on progesterone, oxytocin and prostaglandins. Biol Reprod 1999; 60: 1292-1298.

21. Woclawek-Potocka I, Deptula KM, Bah MM, Lee HY, Okuda K, Skarzynski DJ. Effects of nitric oxide 
on production of prostaglandin $F_{2 \alpha}$ and $E_{2}$ in cultured bovine endometrial cells: cell type specificity. J Reprod Dev 2004: 50: 333-340.

22. Miyamoto Y, Skarzynski DJ, Okuda K. Is tumor necrosis factor- $\alpha$ trigger for the initiation of prostaglandin $\mathrm{F}_{2 \alpha}$ release at luteolysis in cattle? Biol Reprod 2000; 62: 1109-1115.

23. Murakami S, Shibaya M, Takeuchi K, Skarzynski DJ, Okuda K. A passage and storage system for isolated bovine endometrial epithelial and stromal cells. J Reprod Dev 2003; 49: 531-538.

24. Hu J, Braileanu GT, Mirando MA. Oxytocin stimulates prostaglandin $\mathrm{F}$ (2alpha) secretion from porcine endometrial cells through activation of calcium-dependent protein kinase C. Prostaglandins Other Lipid Mediat 2001; 65: 85-101.

25. Kim JJ, Fortier MA. Cell type specificity and protein kinase $\mathrm{C}$ dependency on the stimulation of prostaglandin $\mathrm{E}_{2}$ and prostaglandin $\mathrm{F}_{2 \alpha}$ production by oxytocin and platelet-activating factor in bovine endometrial cells. J Reprod Fertil 1995; 103: 239-247.

26. Szego CM. Mechanisms of hormone action: parallels in receptor-mediated signal propagation for steroid and peptide effectors. Life Sci 1984; 35: 2383-2396.

27. Nabekura J, Oomura $Y$, Minami T, Mizuno $Y$, Fukuda A. Mechanism of the rapid effect of estradiol $17 \beta$ on medial amygdala neurons. Science 1986; 11: 233-226.

28. Aronica SM, Kraus WL, Katzenellenbogen BS. Estrogen action via the cAMP signaling pathway: stimulation of adenylate cyclase and cAMPregulated gene transcription. Proc Natl Acad Sci USA 1994; 91: 8517-8521. 